\title{
The Comparison of Ethanol Extract Breadfruit Leaf and Glibenclamide Towards the Decreasing of Blood Glucose Levels in Rats with Diabetes Mellitus Induced by Alloxan
}

\author{
Iis Inayati Rakhmat \\ Department of Biochemistry, Medical Faculty \\ Universitas Jenderal Achmad Yani \\ Cimahi, Indonesia
}

\author{
Danial Ahmad Dzulfikri* \\ Medical Faculty \\ Universitas Jenderal Achmad Yani \\ Cimahi, Indonesia \\ *danial.ahmad78@gmail.com
}

\author{
Hadi Jusuf \\ Department of Internal Medicine, Medical Faculty \\ Universitas Jenderal Achmad Yani \\ Cimahi, Indonesia
}

\begin{abstract}
Diabetes mellitus is a disease that will increase in the future. There are many drugs used to treat this, but they have a bad side effect when they used for long term. Breadfruit's leaf (Artocarpus altilis) is one of many plants that contains quercetin, a flavonoid that can be used as antidiabetic. This study aimed to determine the effect of ethanol extract of breadfruit's leaf with glibenclamide on blood glucose levels rats (Rattus norvegicus). This research was conducted with experimental methods using 35 rats of wistar strain. They were divided into 5 groups, 1 group as a negative control, and 4 other groups induced by alloxan, further divided into positive control, the treatment group ethanol extract of breadfruit's leaf, the treatment group glibenclamide, and the combination treatment group ethanol extract of breadfruit's leaf with glibenclamid. The result statistical analysis of research by One-Way ANOVA test was significantly different after treatment $(p<0.05)$. Then continued by Post Hoc Tukey test results showed that there were not significantly different among 3 treatment groups. In conclusion ethanol extract of breadfruit's leaf, glibenclamide and the combination treatment group capable of lowering blood glucose levels, but there were no significant differences between three treatment groups.
\end{abstract}

Keywords-antidiabetic, breadfruit's leaf, diabetes melitus, flavonoid, quercetin

\section{INTRODUCTION}

Diabetes Mellitus (DM) is a disease that will increase in number in the future. According to the World Health Organization (WHO), in 2000 the number of DM sufferers over the age of 20 was 150 million people and will continue to increase every year. The number of DM sufferers is estimated to increase to 300 million people in 2025. In 2005, Southeast Asia was the highest region in the world with an incidence of DM sufferers, namely around 80 million people. The incidence of DM in Indonesia has increased quite significantly. According to the 2013 Basic Health Research (Rikesdas), in 2007 DM patients in Indonesia amounted to 5.7\%. In 2013, DM sufferers in Indonesia increased to $6.9 \%$, or around 12,191,564 people [1-3].

Diabetes mellitus is a group of diseases based on metabolic disorders characterized by hyperglycemia as a result of absolute insulin deficiency (type 1 diabetes) or relative insulin deficiency (type 2 diabetes), which is a condition in which high insulin levels are in the blood but its work is ineffective [2-4].

Management of type 2 diabetes mellitus is to apply the principles of 4 pillars, namely education, meal planning, physical activities, and administration of Oral Hypoglycemia (OHO) Drugs. One of the $\mathrm{OHO}$ is glibenclamide which has a mechanism of action to increase insulin secretion from pancreatic beta cells. If glibenclamide is used in the long term or large doses, it will cause side effects in the form of prolonged hypoglycemia and impaired kidney and liver function. Therefore, it is necessary to use alternative medicines derived from plants as has been done by the people of Indonesia since time immemorial. Plants that are empirically used by the community to treat DM include cat whiskers, parang pumpkin leaves, aloe vera leaves, sambiloto, mahogany seeds, and breadfruit leaves [4-11].

The breadfruit plant is one of the plants that is often used as medicine by the community. Breadfruit plants can grow 
throughout the Indonesian archipelago, making them easy to obtain. This plant contains high flavonoids. One type of flavonoid is quercetin which can function as an antioxidant and antidiabetic. Quercetin can inhibit intestinal mucosa glucose transporter (GLUT) 2 so that it can reduce glucose absorption. Also, quercetin can increase insulin secretion from pancreatic beta cells. This results in a reduction in the absorption of glucose and fructose from the intestine so that blood glucose levels fall. So it can be concluded that breadfruit leaves can reduce blood glucose levels. Previous research was conducted by I Putu Ari Wijana Dipa regarding the effect of the ethanol extract of breadfruit leaves on reducing blood glucose levels and it was proven that the ethanol extract of breadfruit leaves at a dose of $100 \mathrm{mg} / \mathrm{kg}$ BW proved to be the most effective in reducing blood glucose levels with the effectiveness of 66.77 . $\%$ [11-15].

In making a diabetic animal model, researchers used male white rats Wistar strain that had been induced by alloxan. Alloxan is a substrate that is structurally a simple pyrimidine derivative that is hydrophilic which can cause diabetes mellitus by inhibiting the glucokinase enzyme and capable of forming free radicals that damage pancreatic beta cells. In this study, a dose of $120 \mathrm{mg} / \mathrm{kg}$ body weight was used intraperitoneally $[16,17]$.

But in reality, herbal plants have not been able to fully replace the function of chemical drugs, so diabetes mellitus patients do not allow to consume only breadfruit leaves without OHO. Therefore, researchers are interested in examining the extent to which the effect of the ethanol extract of breadfruit leaves on diabetes mellitus compared to glibenclamide and the use of breadfruit leaf ethanol extract combined with glibenclamide in reducing blood glucose levels of alloxaninduced rats [18].

\section{RESEARCH METHODS}

\section{A. Tool}

The tools needed in this research are macerator, tissue, cotton pad, rotary evaporator, filter paper, extract container, refrigerator, balance as a means of making breadfruit leaf ethanol extract. Centrifuge, spectrophotometer, cuvette, test tube, ependorphous tube, micropipette as a means of checking blood glucose. Sonde (force-feeding needle), $3 \mathrm{ml}$ syringe, and mouse cage in the form of a plastic box with open top and covered with the woven wire as tools used when treating mice.

\section{B. Material}

1) Test material: The test material used in this study was the ethanol extract of breadfruit leaves. The breadfruit leaves used to make the extract are collected from the breadfruit tree that grows in the Cibeber-Cilegon plantation. The leaf selection criterion used is that the leaves are quite old and grow on the 3rd to 7th leaves from the shoots of the stem.

2) Chemical material: $96 \%$ ethanol, alloxan, distilled water, blood glucose reagent, standard solution.
3) Test animals: The animals used in this study were male white rats Wistar strain, with bodyweight ranging from 200300 grams, aged 2 - 3 months, as many as 35 tails. These mice were obtained from Biofarma Bandung.

\section{Procedure}

1) Preparation of test animals: There were 35 rats used and an adaptation was carried out for 14 days in the animal cage of the Faculty of Animal Unjani. Weighing body weight was carried out at the first time of collection and before alloxan induction $120 \mathrm{mg} / \mathrm{kg} \mathrm{BW}$ intraperitoneally and before being given treatment. Rats were divided into 5 groups, namely negative control, positive control, and 3 treatment groups.

2) Treatment: After 14 days of adaptation, the control group and 3 treatment groups were induced by alloxan 120 $\mathrm{mg} / \mathrm{kg} \mathrm{BW}$. The next day, blood was drawn through the orbital veins of the mice to measure the first blood glucose levels. Furthermore, each group was treated in the form of giving 100 $\mathrm{mg} / \mathrm{kg} \mathrm{BW}$ breadfruit leaf ethanol extract and $0.45 \mathrm{mg} / \mathrm{kg} \mathrm{BW}$ glibenclamide inserted into the stomach of the rats using an oral sonde. The dose given was adjusted according to the bodyweight of the mice. The negative control and positive control were not given breadfruit leaf ethanol extract and glibenclamide, while in treatment group 1 was given breadfruit leaf ethanol extract $100 \mathrm{mg} / \mathrm{kg} \mathrm{BW}$, treatment group 2 was given glibenclamide $0.45 \mathrm{mg} / \mathrm{kg} \mathrm{BW}$, and treatment group 3 was given a combination of ethanol extract. breadfruit leaves $100 \mathrm{mg} / \mathrm{kg} \mathrm{BW}$ and glibenclamide $0.45 \mathrm{mg} / \mathrm{kg} \mathrm{BW}$. The treatment was carried out for 21 days. On the following day, another blood draw was carried out for the second measurement of blood glucose levels.

\section{RESULTS AND DISCUSSION}

\section{A. Effect of Treatments on Blood Glucose Levels}

The blood glucose level of the rats was first checked after being induced by alloxan $120 \mathrm{mg} / \mathrm{kg} \mathrm{BW}$, except for the negative control group. In this study all alloxan-induced rats experienced hyperglycemia. Then continued the treatment in each group for 21 days. Furthermore, the second examination of blood glucose levels was carried out, so that there was a decrease in all treatment groups. The difference in blood glucose levels before and after all groups can be seen in Figure 1 . 


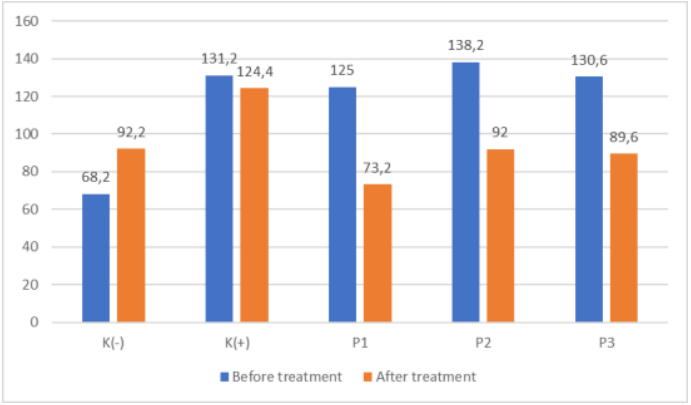

Fig. 1. Differences in blood glucose levels before and after treatment.

To find out the significant difference from the difference in blood glucose levels before and after treatment, it was continued using the paired T-test. The results for the difference in blood glucose levels before and after treatment are shown in Table 1.

TABLE I. DIFFERENCE IN REDUCTION OF BLOOD GLUCOSE LEVELS BEFORE AND AFTER TREATMENT

\begin{tabular}{|c|c|c|c|c|c|}
\hline No & Group & $\begin{array}{c}\text { Average } \\
\text { blood } \\
\text { glucose } \\
\text { levels } \\
\text { before } \\
\text { treatment } \\
\text { (mg/dl) } \\
\end{array}$ & $\begin{array}{c}\text { Average } \\
\text { blood } \\
\text { glucose } \\
\text { levels after } \\
\text { treatment } \\
\text { (mg/dl) }\end{array}$ & $\begin{array}{c}\text { Average } \\
\text { difference } \\
\text { blood } \\
\text { glucose } \\
\text { (mg/dl) }\end{array}$ & $P$ value \\
\hline 1 & $\mathrm{~K}(-)$ & $68,2 \pm 9,985$ & $\begin{array}{l}92,2 \\
1,789\end{array}$ & -24 & $0,008^{*}$ \\
\hline 2 & $\mathrm{~K}(+)$ & $\begin{array}{l}131,2 \\
13,084\end{array} \quad \pm$ & $124 \pm 0,98$ & 6,8 & 0,356 \\
\hline 3 & P1 & $\begin{array}{ll}125 & \pm \\
13,528 & \\
\end{array}$ & $\begin{array}{ll}73,2 & \pm \\
3,633 & \\
\end{array}$ & 51,8 & $0,002^{*}$ \\
\hline 4 & $\mathrm{P} 2$ & $\begin{array}{l}138,2 \quad \pm \\
21,441\end{array}$ & $92 \pm 7,616$ & 46,2 & $0,021^{*}$ \\
\hline 5 & P3 & $\begin{array}{ll}130,6 & \pm \\
8,325 & \end{array}$ & $\begin{array}{ll}89,6 & \pm \\
6,465 & \end{array}$ & 41 & $0,000^{*}$ \\
\hline
\end{tabular}

Note:

$\mathrm{K}(-)=$ negative control

$\mathrm{K}(+)=$ positive control

$\mathrm{P} 1=$ the ethanol extract of breadfruit leaves treatment group

$\mathrm{P} 2$ = glibenclamide treatment group

P3 = combination between the ethanol extract of breadfruit leaves and the glibenclamide treatment group

Based on the results of the paired T-test in the table above, all groups induced by alloxan experienced an increase in blood glucose levels. This is thought to be caused by alloxan which can damage pancreatic beta cells. Alloxan is selectively toxic to pancreatic beta cells because it can enter through GLUT 2 because of its similar structure to glucose. In this study, alloxan was thought to be able to inhibit the glucokinase enzyme found in pancreatic beta cells, thereby reducing the formation of ATP which is useful for secreting insulin. Alloxan is also able to form reactive oxygen species (ROS) in pancreatic beta cells, resulting in damage to pancreatic beta cells. These 2 mechanisms are thought to be able to cause an increase in blood glucose levels in mice. In the positive control group, there was a decrease in blood glucose levels on the second examination of blood glucose levels. This is thought to be caused by one of the deficiencies of alloxan, which is reversible so that pancreatic beta cells can regenerate from damage caused by free radicals after being induced by alloxan [15].

In the negative control group, there was no increase in glucose levels at the time of the first examination of blood glucose levels because it was not induced by alloxan. In this study, the pancreatic beta cells in these mice were thought to be able to secrete insulin according to their function. When glucose from food consumed by rats circulates in the blood, it will enter the beta cells of the pancreas through GLUT 2. The glucose will be diglycolyzed by the enzyme glucokinase to produce ATP. ATP activates the process of closing the $\mathrm{K}$ channels contained in the cell membrane. Inhibition of releasing $\mathrm{K}$ ions from the cell causes depolarization of the cell membrane, which is followed by the process of opening $\mathrm{Ca}$ canals. Furthermore, $\mathrm{Ca} 2+$ ions will stimulate insulin secretion from the granules. Ultimately, insulin is secreted. Insulin will circulate in the blood and then attach to the IRS which is on the cell membrane. This bond causes the activation of GLUT 4 so that it can increase the quantity of GLUT 4 on the target cell membrane. GLUT 4 has the role of entering glucose into cells so that glucose levels in the blood of mice decrease within normal limits. However, from the results of this study, in the negative control, there was an increase in blood glucose levels at the time of the second glucose level examination, although it was still within normal limits. This is presumably due to excessive food intake at the time of treatment. The food given is not proportional to one rat but rather given in a container that can be consumed by all rats.

All treatment groups were able to cause a decrease in blood glucose levels. This is thought to be due to a mechanism that can reduce blood glucose levels in the ethanol extract of breadfruit leaves and glibenclamide. This result is by the research conducted by I Putu Ari Wijana Dipa which proved that the ethanol extract of breadfruit leaves $100 \mathrm{mg} / \mathrm{kg} \mathrm{BW}$ can reduce blood glucose levels of alloxan-induced rats [14].

In this study, the ethanol extract of breadfruit leaves was thought to contain substances such as quercetin, which is a flavonoid. The flavonoids contained in breadfruit leaves can act as antioxidants. Flavonoids have the effect of reducing oxidative stress by binding to free radicals. Finally, it is proven that breadfruit leaves can maintain the integrity of pancreatic beta cells. Quercetin is a flavonoid type of flavonol. This substance can reduce glucose in the blood by inhibiting GLUT 2 in the intestinal epithelial cells so that the absorption of glucose by the intestine is inhibited. Also, quercetin can increase the influx of $\mathrm{Ca} 2+$ in the beta-cell membrane of the pancreas so that insulin-filled granules are capable of exocytosis, so that insulin levels in the blood increase [9$13,15]$. 
Glibenclamide has the same effect as one of the mechanisms of the ethanol extract of breadfruit leaves in reducing blood glucose levels by increasing insulin secretion by pancreatic beta cells. This can occur because this drug can stimulate insulin secretion from the granules of pancreatic beta cells through its interaction with the ATP-sensitive $\mathrm{K}$ channel on the pancreatic beta-cell membrane $[7,8]$.

\section{B. Comparion of the Effectiveness of Each Treatment}

By the previous explanation states that the test for the difference in blood glucose levels using paired T-test statistical analysis in all treatment groups has a p-value $<0.05$. This indicates that there are significant differences before and after treatment. In this study, it was continued with the One-Way ANOVA test to determine the differences between all treatment groups including the negative control group and the positive group. The hypothesis in the One-Way ANOVA test is Ho: $\mathrm{a}=0$ (data between the five groups has no difference), or Ha: $a \neq 0$ (data between the five groups has differences) with the test criteria, namely Ho is rejected if the significance of the $\mathrm{P}$-value $<0.05$.

The One-Way ANOVA test in the control group and the treatment group showed that the five treatments had significant differences with the resulting $\mathrm{F}$ test value of 18.288 with a significance value of $p=0.000$ or $p$-value $<0.05$, so the Ho hypothesis was rejected. This shows that there is a very significant difference in blood glucose levels in more than 2 groups so that it can be continued with the post hoc test to find out how the differences between each group are. The post hoc test in this study used the Tukey test with the results listed in Table 2.

TABLE II. COMPARISON OF THE DIFFERENCES IN BLOOD GLUCOSE LEVELS FOR EACH GROUP

\begin{tabular}{|l|l|l|}
\hline \multicolumn{1}{|c|}{ Group } & \multicolumn{1}{|c|}{ Comparison group } & \multicolumn{1}{c|}{ P value } \\
\hline $\mathrm{K}(-)$ & $\mathrm{K}(+)$ & 0,062 \\
\hline & $\mathrm{P} 1$ & $0,000 *$ \\
\hline & $\mathrm{P} 2$ & $0,000^{*}$ \\
\hline & $\mathrm{P} 3$ & $0,000^{*}$ \\
\hline $\mathrm{K}(+)$ & $\mathrm{P} 1$ & $0,003^{*}$ \\
\hline & $\mathrm{P} 2$ & $0,011^{*}$ \\
\hline & $\mathrm{P} 3$ & $0,032^{*}$ \\
\hline $\mathrm{P} 1$ & $\mathrm{P} 2$ & 0,984 \\
\hline & $\mathrm{P} 3$ & 0,846 \\
\hline $\mathrm{P} 2$ & $\mathrm{P} 3 \quad$ *Tukey test results: $\mathrm{p}<0.05$ (there is a significant difference) \\
\hline
\end{tabular}

Note: Values with different letters $(\mathrm{a}, \mathrm{b})$ in the same column indicate a significant difference (Tukey $\mathrm{P}$ test $<0.05$ ), while values with the same letter in the same column indicate no significant difference (Tukey $\mathrm{P}$ test $>0,05$ ).

$\mathrm{K}(-)$ = negative control

$\mathrm{K}(+)=$ positive control

$\mathrm{P} 1=$ the ethanol extract treatment group of breadfruit leaves

$\mathrm{P} 2$ = glibenclamide treatment group
P3 = combination group between the ethanol extract of breadfruit leaves and the glibenclamide group

In the Tukey test, the results showed that all treatment groups had significant differences with the negative and positive control groups, this indicated that the ethanol extract of breadfruit leaves, glibenclamide, and the combination of the ethanol extract of breadfruit leaves and glibenclamide affected reducing blood glucose levels. Based on the P-value in each treatment group did not choose. There are significant differences, so it can be concluded that the ethanol extract of breadfruit leaves, glibenclamide, and the combination of breadfruit leaf extract and glibenclamide did not show significant differences between treatment groups.

The ethanol extract of breadfruit leaves and glibenclamide was able to reduce blood glucose levels in rats, but not until the glucose levels experienced hypoglycemia. This is thought to be due to a process that occurs in the rats' bodies to maintain normal blood glucose levels so that this study did not show any significant differences between treatment groups.

The combination group between the ethanol extract of breadfruit leaves and glibenclamide reduced blood glucose levels no better than the breadfruit leaf extract group and the glibenclamide group. This requires further research to prove whether the combination of the ethanol extract of breadfruit leaves with glibenclamide can cause pharmaceutic, pharmacokinetic, or pharmacodynamic interactions that can reduce the performance of the ethanol extract of breadfruit leaves, glibenclamide, or both.

\section{CONCLUSION}

Breadfruit leaf ethanol extract $100 \mathrm{mg} / \mathrm{kg}$ BW, glibenclamide $0.45 \mathrm{mg} / \mathrm{kg} \mathrm{BW}$, and a combination of breadfruit leaf ethanol extract $100 \mathrm{mg} / \mathrm{kg} \mathrm{BW}$ with glibenclamide 0.45 $\mathrm{mg} / \mathrm{kg} \mathrm{BW}$ can reduce blood glucose levels in diabetes mellitus rats induced by alloxan. However, there was no significant difference between treatment groups.

\section{REFERENCES}

[1] S. Suyono, Diabetes Mellitus in Indonesia. In: S. Setiati, I. Alwi, A.W. Sudoyo, M. Simadibrata, B. Setiyohadi, and A.F. Syam, Eds. Textbook of disease science in volume II. Edition 6. Jakarta: Interna Publishing, 2014, pp. 2315-22.

[2] Ministry of Health, "Basic Health Research 2013," [online]. Retrieved from http: // www. depkes.go.id/resources/download/general/Hasil\%20Riskesdas\%202013. pdf

[3] Center for Data and Information of the Ministry of Health of the Republic of Indonesia, "Diabetes situation and analysis," [online[. Retrieved from http://www.depkes.go.id/resources/download/pusdatin/infodatin/ infodatin-diabetes.pdf

[4] D. Purnamasari, Diagnosis and classification of Diabetes Mellitus. In: S. Setiati, I. Alwi, A.W. Sudoyo, M. Simadibrata, B. Setiyohadi, A.F Syam, Eds. Textbook of disease science in volume II. Edition 6. Jakarta: Interna Publishing, 2014, pp. 2323-6. 
[5] S. Soegondo, Pharmacotherapy in controlling glycemia Type 2 Diabetes Mellitus In: S. Setiati, I. Alwi, A.W. Sudoyo, M. Simadibrata, B Setiyohadi, and A.F. Syam, Eds. Textbook of disease science in volume II. Edition 6. Jakarta: Interna Publishing; 2014, pp. 2328-35.

[6] Arisman, Obesity, diabetes mellitus \& dyslipidemia: concepts, theories, and applicable management. Jakarta: EGC Medical Book, 2013, pp. 44120.

[7] S.K. Suherman, Insulin and oral antidiabetic. In: Gunawan SG, Setiabudy R, Nafrialdi, Elysabeth, Eds. Pharmacology and therapy. Edition 5. Jakarta: FKUI Publisher Center, 2009, pp. 481-95.

[8] Indonesian Association of Endocrinologists (PERKENI), "Consensus on the management \& prevention of type 2 Diabetes Mellitus in Indonesia 2006," [online]. Retrieved from http: // www. pbpapdi.org/images/file_guidelines/12_Konsensus\%20Penggawaialn\%2 0dan\%20P

Prevention\%20Diabets\%20Melitus\%20Tipe\%202\%20di\%20Indonesia $\% 202006 . P D F$

[9] Settlements, "Utilization of family medicinal plants (toga) for family health," [online]. Retrieved from http://library.usu.ac.id/download/fkm/fkm-tukiman.pdf

[10] Drug and Food Control Agency of the Republic of Indonesia, "Drug and Food Supervisory Info," [online]. Retrieved from http://www.perpustaka.pom.go.id/KoleksiLain/ Bulletin\% 20Info\% 20POM / 0304.pdf.

[11] U.B. Jagtap and V.A. Bapat, "Artocarpus: A review of its traditional uses, phytochemistry, and pharmacology," Journal of Ethnopharmacology, vol. 129, pp. 142-66, 2010.
[12] A. Intanowa, The effect of the ethanol extract of breadfruit leaves on blood sugar levels in alloxan-induced diabetes mellitus rats. Bali: Faculty of Medicine, Udayana University, 2012.

[13] J. Song, O. Kwon, S. Chen, R. Daruwala, P. Eck, J.B. Park, and M. Levine, "Flavonoid inhibition of SVCT1 and GLUT2, intestinal transporters for vitamin C and glucose," J Biol Chem, vol. 277, pp. 15252-60, 2002.

[14] M. Kittl, M. Beyreis, M. Tumurkhuu, J. Furst, K. Helm, and A Pitschmann, "Quercetin stimulates insulin secretion and reduces the viability of rat INS-1 beta-cells," Cell Physiol Biochem, vol. 39, pp. 278-93, 2016

[15] I.P.A.W. Dipa, N.W. Sudatri, and N.I. Wiratmini, "The effectiveness of breadfruit leaf extract (Artocarpus communis forst.) In lowering blood glucose levels and maintaining sperm count in rats (Rattus norvegicus)," Journal of Symbiosis, vol. 1, pp. 317-21, 2015.

[16] S. Lenzen, "The mechanism of alloxan- and streptozotocin-induced diabetes," Diabetologia, vol. 51, pp. 216-26, 2008.

[17] N. Suarsana, B.P. Priyosoeryanto, M. Bintang, and T. Wresdiyanti, "Profile of blood glucose and ultrastructure of rat pancreatic beta cells induced by alloxan compounds," JITV, vol. 15, pp. 118-23, 2010.

[18] Hernani, "Development of biopharmaceuticals as an herbal medicine for health.," [online]. Retrieved from http://pascapanen.litbang.pertanian.go.id/assets/media/publikasi/bulletin/ Buletin_Pascapanen_7.1_3_2011.pdf. 